Vol. 5 (1996): 421-430.

\title{
Carbon dioxide evolution from snow-covered agricultural ecosystems in Finland
}

\author{
Hiroshi Koizumi \\ Division of Plant Ecology, National Institute of Agro-Environmental Sciences, Tsukuba, Ibaraki, 305 Japan \\ Markku Kontturi \\ Agricultural Research Centre of Finland, Institute of Crop and Soil Science, FIN-31600 Jokioinen, Finland \\ Shigeru Mariko \\ Sugadaira Montane Research Center, University of Tsukuba, Sanada, Nagano, 386-22 Japan \\ Timo Mela \\ Agricultural Research Centre of Finland, Institute of Crop and Soil Science, FIN-31600 Jokioinen, Finland
}

\begin{abstract}
The release of $\mathrm{CO}_{2}$ from the snow surface in winter and the soil surface in summer was directly or indirectly measured in three different soil types (peat, sand and clay) in agricultural ecosystems in Finland. The closed chamber (CC) method was used for the direct and Fick's diffusion model (DM) method for the indirect measurements. The winter soil temperatures at $2-\mathrm{cm}$ depth were between 0 and $1{ }^{\circ} \mathrm{C}$ for each soil type. The concentration of $\mathrm{CO}_{2}$ within the snowpack increased linearly with snow depth. The average fluxes of $\mathrm{CO}_{2}$ calculated from the gradients of $\mathrm{CO}_{2}$ concentration in the snow using the DM method ranged from 10 to $27 \mathrm{mg} \mathrm{CO}_{2} \mathrm{~m}^{-2} \mathrm{~h}^{-1}$, and with the $\mathrm{CC}$ method from 18 to $27 \mathrm{mg} \mathrm{CO}_{2} \mathrm{~m}^{-2} \mathrm{~h}^{-1}$. These results suggest that the snow insulates the soil thermally, allowing $\mathrm{CO}_{2}$ production to continue at soil temperatures slightly above freezing in the winter. Carbon dioxide formed in the soil can move across the snowpack up to the atmosphere. The winter/summer ratio of $\mathrm{CO}_{2}$ evolution was estimated to exceed $4 \%$. Therefore, the snow-covered crop soil served as a source of $\mathrm{CO}_{2}$ in winter, and $\mathrm{CO}_{2}$ evolution constitutes an important part of the annual $\mathrm{CO}_{2}$ budget in snowy regions.
\end{abstract}

Key words: closed chamber method, $\mathrm{CO}_{2}$ flux, $\mathrm{CO}_{2}$ profile, heavy clay soil, peat soil, sand soil, snowpack, soil respiration, subarctic climate region

\section{Introduction}

Carbon dioxide is the primary gas involved in the exchange of carbon between the atmosphere and the soil. Budgets assume that microorganisms and plant roots in snow-covered soils stop respiring and so there is no evolution of $\mathrm{CO}_{2}$ from the snow surface when soil temperatures drop to around $0^{\circ} \mathrm{C}$ (Steudler et al. 1989, Bouw- 


\section{AGRICULTURAL AND FOOD SCIENCE IN FINLAND}

Koizumi, H. et al. Carbon dioxide evolution from agricultural ecosystems

man 1990). Thus the contribution of $\mathrm{CO}_{2}$ from alpine or arctic regions in winter has not been considered important in calculations of global carbon balances. Some reports have, nevertheless, shown that $\mathrm{CO}_{2}$ concentrations are high at the base of snowpacks in arctic and temperate regions (Kelley et al. 1968, Solomon and Cerling 1987). In addition, there is some evidence that microorganisms in soils beneath the snow continue to respire at temperatures close to $0^{\circ} \mathrm{C}$ (Taylor and Parkinson 1988, Sommerfeld et al. 1991). It is currently thought that the soils under alpine and sub-alpine snowpacks evolve $\mathrm{CO}_{2}$ to the atmosphere throughout the snow-covered period (Sommerfeld et al. 1993, Mariko et al. 1994).

Snow can cover between $44 \%$ and $53 \%$ of the land area of the northern hemisphere, and in alpine and sub-alpine regions it may be several meters deep for more than half the year (Barry 1992). Sommerfeld et al. (1993) reported that $\mathrm{CO}_{2}$ fluxes through snowpacks in these regions ranged from 31 to $84 \mathrm{mg} \mathrm{CO}_{2} \mathrm{~m}^{-2} \mathrm{~h}^{-1}$, as calculated from Fick's law. If snow-covered soils show some $\mathrm{CO}_{2}$ evolution in winter, the $\mathrm{CO}_{2}$ released can strongly influence the annual global carbon budget. This flux needs to be measured urgently for a more complete understanding of the global carbon balance. However, not only $\mathrm{CO}_{2}$ fluxes from the snow surface but also $\mathrm{CO}_{2}$ concentrations in the snowpack have rarely been measured (Coyne and Kelley 1974, Solomon and Cerling 1987). In particular, no researcher has measured the fluxes directly with chamber methods.

The aim of the present study is to measure directly or indirectly the $\mathrm{CO}_{2}$ released from the snow surface in winter and the soil surface in summer in three different soil types in agricultural ecosystems in Finland. The closed chamber (CC) method (Bekku et al. 1995, Bekku et al. 1996) was used for the direct measurement. For methodological comparison, the $\mathrm{CO}_{2}$ fluxes were measured with Fick's diffusion model (DM), which so far has been used as an indirect method (Rolston 1986).

\section{Material and methods}

\author{
Study site
}

The investigations were carried out in experimental fields of the Agricultural Research Centre of Finland (ARCF) in July 1992 and March 1994. The fields were located at Jokioinen $\left(60^{\circ} 9^{\prime} \mathrm{N}, 23^{\circ} 0\right.$ ' E, $104 \mathrm{~m}$ asl) in southern Finland. Meteorological data at the ARCF site showed that annual precipitation averaged $581 \mathrm{~mm}$, the mean annual temperature was $3.9^{\circ} \mathrm{C}$ and the average snow depth in March was $39 \mathrm{~cm}$ during the period from 1961 to 1990 . The monthly mean temperature in July 1992 was $16.0^{\circ} \mathrm{C}$ and in March $1994-3.2^{\circ} \mathrm{C}$. The warmth index at this site was 38.1 degree-months, indicating that the site is in the subarctic climate range.

Three barley fields consisting of three different soil types were investigated. Classified on the Finnish and FAO system, the soils were peat (histosol), sand (cambisol) and heavy clay (cambisol). Table 1 lists the cultivation methods for each soil type in the agricultural ecosystems. Spring barley was cultivated in one field from the middle of May to the end of August, after which the field was fallowed from September to the following April.

After the measurements of $\mathrm{CO}_{2}$ flux in winter, snow pits were dug beneath five flux-measurement points in each soil type to assess snow depth and porosity (Sommerfeld et al. 1993). At the same time, air temperatures were measured $50 \mathrm{~cm}$ above the snow or at the soil surface, snow temperatures at $10-\mathrm{cm}$ depth and/or soil temperatures at 2-cm depth in winter and summer. The temperatures were measured with a digital-reading, spike stem, dual metallic thermometer.

\section{Measurement of $\mathrm{CO}_{2}$ flux using the $\mathrm{CC}$ method}

The evolution of $\mathrm{CO}_{2}$ from the soil surface in summer and from the snow surface in winter was 
Vol. 5 (1996): 421-430.

Table 1. Cultivation methods of spring barley in three soil types in agricultural ecosystems.

\begin{tabular}{lcccccl}
\hline Soil type & Growth period & Variety & $\begin{array}{c}\text { Seeds } \\
\left(\mathrm{g} \mathrm{m}^{-2}\right)\end{array}$ & $\begin{array}{c}\text { Row space } \\
(\mathrm{cm})\end{array}$ & $\begin{array}{c}\mathrm{N} \text { fertilizer } \\
\left(\mathrm{g} \mathrm{m}^{-2}\right)\end{array}$ & $\begin{array}{l}\text { Fallowing } \\
\text { period }\end{array}$ \\
\hline Peat soil & 15May $\sim$ 25Aug. & Jo1545 & 19.0 & 12.5 & 6.0 & Sept. $\sim$ following April \\
Sand soil & 15May 20Aug. & Jo1545 & 19.0 & 12.5 & 9.2 & Sept. $\sim$ following April \\
Clay soil & 12May 20Aug. & Jo1545 & 19.0 & 12.5 & 9.2 & Sept. $\sim$ following April \\
\hline
\end{tabular}

measured on 14 July 1992 and 18 March 1994, respectively, for the peat soil, on 14 July 1992 and 18 March 1994 for the sand soil, and on 16 July 1992 and 18 March 1994 for the clay soil. The flux was measured at five points in each soil type during a diurnal period lasting from 10:00 to $14: 00$.

The $\mathrm{CO}_{2}$ flux was determined directly in situ with the CC method, because this method can be used at sites where electricity or special equipment is not available. In this method, a closed chamber is placed over the soil or snow surface and the increase in the concentration of $\mathrm{CO}_{2}$ within the chamber is measured as a function of time. The $\mathrm{CO}_{2}$ flux is calculated from Eq. (1).

$$
F=(V / A)(\Delta C / \Delta t),
$$

where $F$ is the $\mathrm{CO}_{2}$ flux $\left(\mathrm{mg} \mathrm{CO} \mathrm{m}^{-2} \mathrm{~h}^{-1}\right), V$ is the volume of air within the chamber $\left(\mathrm{m}^{3}\right), A$ is the area of the soil or snow within the chamber $\left(\mathrm{m}^{2}\right)$, and $\Delta C / \Delta t$ is the rate of change in the $\mathrm{CO}_{2}$ concentration in the air within the chamber $\left(\mathrm{mg} \mathrm{CO}_{2} \mathrm{~m}^{-3} \mathrm{~h}^{-1}\right)$.

A polyvinyl-chloride cylinder (15-cm high, $21-\mathrm{cm}$ internal diameter) was placed on the soil or snow surface. About an hour later, the cylinder was closed with a polyvinyl-chloride lid, and a rubber-capped (blood collection) needle was fitted onto an air sample port on the top of the lid. Air in the chamber was aspirated through the needle into an evacuated vial $(5 \mathrm{ml})$ three times at equal intervals ( 2 or 5 minutes), and the $\mathrm{CO}_{2}$ concentration in the vial air was measured as described in the previous paper (Mariko et al. 1994). The concentration of $\mathrm{CO}_{2}$ was plotted against the time (Fig. 1).
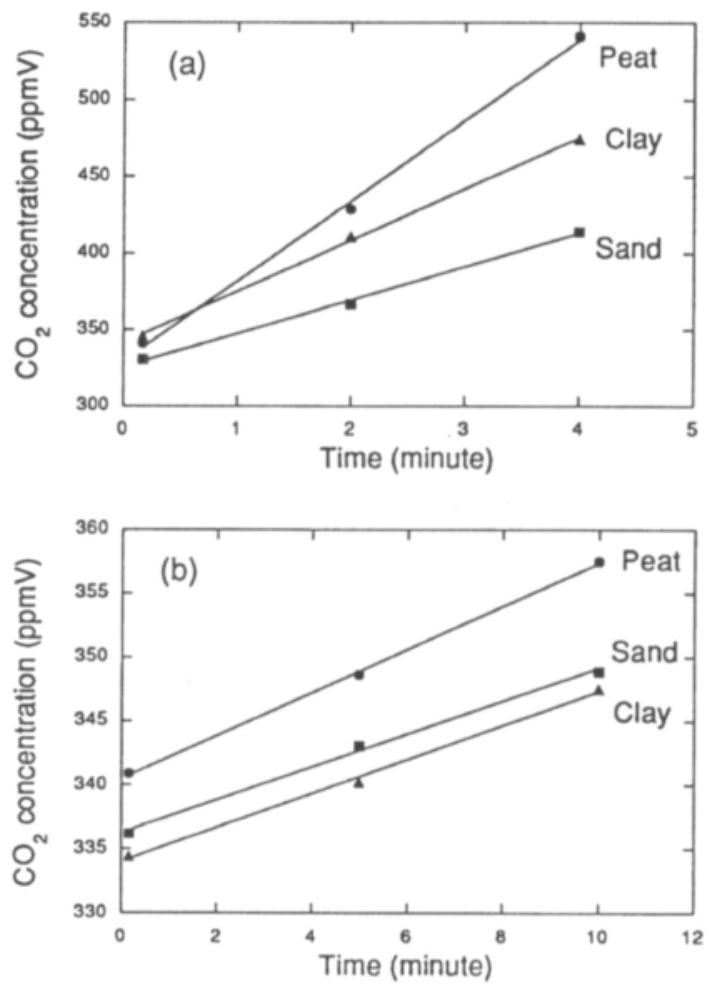

Fig. 1. Typical time courses of $\mathrm{CO}_{2}$ concentration in a chamber of the CC method in (a) summer and (b) winter. Results were selected to illustrate the lowest and highest rates of $\mathrm{CO}_{2}$ increase on summer and winter days for three soil types. Regression equations and correlation coefficients:
(a): Peat (-); $\mathrm{Y}=52.281 \mathrm{X}+329.24, \mathrm{R}^{2}=0.998$
Sand
(a); $\mathrm{Y}=21.910 \mathrm{X}+325.34, \mathrm{R}^{2}=0.997$
Clay
(A); $\mathrm{Y}=33.472 \mathrm{X}+341.39, \mathrm{R}^{2}=0.999$
(b): Peat
(); $\mathrm{Y}=1.6892 \mathrm{X}+340.46, \mathrm{R}^{2}=0.999$
Sand
(घ); $\mathrm{Y}=1.2912 \mathrm{X}+336.20, \mathrm{R}^{2}=0.996$
Clay
(A); $\mathrm{Y}=1.3334 \mathrm{X}+333.96, \mathrm{R}^{2}=0.997$ 


\section{AGRICULTURAL AND FOOD SCIENCE IN FINLAND}

Koizumi, H. et al. Carbon dioxide evolution from agricultural ecosystems

\section{Profile of $\mathrm{CO}_{2}$ concentration in snowpack}

The concentration gradient of $\mathrm{CO}_{2}$ in the snowpack and atmosphere was determined on the same day as the direct determination of the $\mathrm{CO}_{2}$ flux. Air was sampled, using the gas collector described in a previous paper (Mariko et al. 1994), at various depths below or above the closed chamber. The air sampling ports were installed at different snow depths. Snow air was drawn through the needle with an evacuated sampling vial $(5 \mathrm{ml})$. Some air (about $2 \mathrm{ml}$ ) in the gas collector was previously removed with a gastight syringe connected to the needle at the end of the gas collector. The air samples were taken twice at two lateral locations at the same snow depth to obtain a more representative concentration at a particular depth.

\section{Calculation of $\mathrm{CO}_{2}$ evolution from snow surface using Fick's DM}

The evolution of $\mathrm{CO}_{2}$ from the snowpack in winter was calculated assuming simple diffusion, average $\mathrm{CO}_{2}$ gradients, average snow depth and average porosities (Sommerfeld et al. 1993, Mariko et al. 1994). The diffusion of gases in the snowpack can be described by Fick's first law, which states that the steady state transport of gas by diffusion through a unit area is proportional to the concentration gradient measured along the line normal to the area:

$$
F=-a D p(d C / d z),
$$

where $F$ is the $\mathrm{CO}_{2}$ flux $\left(\mathrm{mg} \mathrm{CO} \mathrm{Cm}^{-2} \mathrm{~h}^{-1}\right), a$ is a constant for unit conversion ( 36 as a value), $D p$ is the diffusion coefficient $\left(\mathrm{cm}^{2} \mathrm{~s}^{-1}\right)$ and $d C /$ $d z$ is the vertical concentration gradient of $\mathrm{CO}_{2}$ $\left(\mathrm{mg} \mathrm{CO} \mathrm{m}^{-3} \mathrm{~cm}^{-1}\right)$. The term $d C / d z$ can be determined directly by drawing a straight line through the average concentrations from the snow surface to $20-\mathrm{cm}$ depth $\left(\mathrm{CO}_{2}\right.$ profile $)$ and by calculating the slope.

The diffusion coefficient $D p$ is influenced by the atmospheric pressure and temperature in situ. $D p$ for $\mathrm{CO}_{2}$ in snow can be estimated from Eq. (3):

$$
D p=D_{0} \theta \lambda,
$$

where $D_{0}$ is the diffusion coefficient of $\mathrm{CO}_{2}$ in air $\left(\mathrm{cm}^{2} \mathrm{~s}^{-1}\right), \theta$ is the porosity of the snow measured $\left(\mathrm{cm}^{3} \mathrm{~cm}^{-3}\right)$, and $\lambda$ is the empirical tortuosity factor $\left(\mathrm{cm} \mathrm{cm}^{-1}\right)$ (van Bavel 1951). $D_{0}$ was corrected for the temperature $\left(T,{ }^{\circ} \mathrm{K}\right)$ and the atmospheric pressure $(P, \mathrm{hPa})$ at each study area from Eq. (4):

$$
D_{0}(T, P)=D_{0}(S)(T / 273)^{n} 1013 / P .
$$

$T$ and $P$ were estimated from the meteorological data of the Meteorological Observatory of the Agricultural Research Centre of Finland. $D_{0}(S)$ is the diffusion coefficient at the normal state (the empirical value $0.135 \mathrm{~cm}^{2} \mathrm{~s}^{-1}$ for $\mathrm{CO}_{2}$ ) and an exponent $n$ is 1.71 for $\mathrm{CO}_{2}$ (Osozawa 1987). The tortuosity factor for snow was not measured here. However, the constant value of 0.69 estimated from the data of Sommerfeld et al. (1993) was adopted. This value is appropriate since the porosities influencing tortuosity were almost constant over the snow depths measured, and similar to those (c. 0.58) of Sommerfeld et al. (1993) and Solomon and Cerling (1987). The average porosity of snow was between 0.53 and 0.59 at all measurement points.

\section{Measurement of $\mathrm{CO}_{2}$ concentration of air stored in the sampling vial}

The concentration of $\mathrm{CO}_{2}$ in the air stored in the sampling vial was determined with an infrared gas analyser, IRGA (Model ZRC, Fuji Elec. Tokyo, Japan). A 1- or 2-ml aliquot of air in the vial was removed with a gas-tight syringe (2-ml volume). During the withdrawal, the air removed was replaced with distilled water, adjusted at $\mathrm{pH} 4.0$ with phosphoric acid $\left(\mathrm{H}_{3} \mathrm{PO}_{4}\right)$. The withdrawn air was injected into a gas line purged with 


\section{AGRICULTURAL AND FOOD SCIENCE IN FINLAND}

Vol. 5 (1996): 421-430.
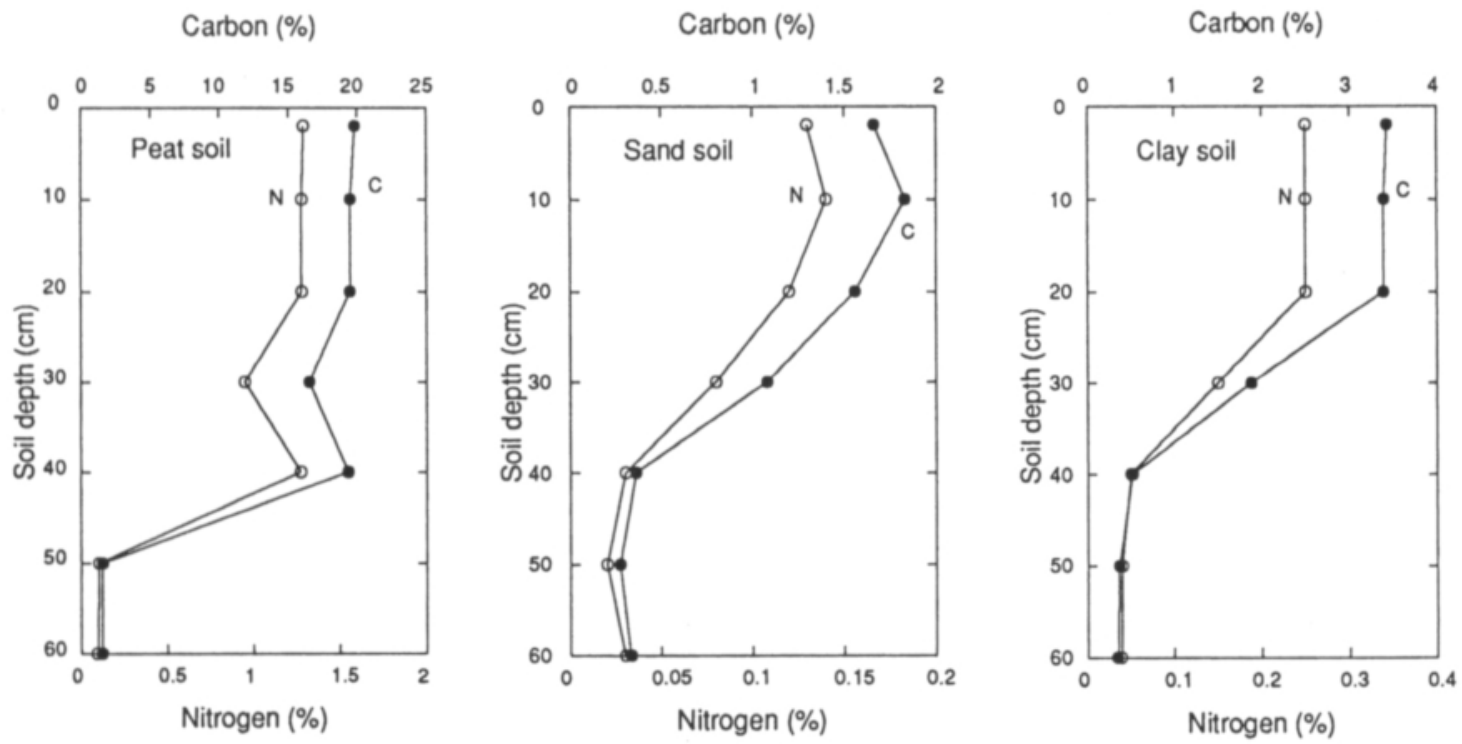

Fig 2. Vertical distribution of soil carbon and nitrogen contents (\%, dry weight basis) in peat, sand and clay soil fields.

$\bullet$, carbon content; $\bigcirc$, nitrogen content

pure $\mathrm{N}_{2}$ gas at a flow rate of $0.5 \mathrm{ml} \mathrm{min}^{-1}$. This gas line allowed the injected air to reach the IRGA in several seconds. The electric output from the IRGA was recorded as a steep peak, like a spike on a pen recorder (Servocorder SR6312, Graphtec, Tokyo, Japan). The spike heights $(\mathrm{X})$ were used for quantitative analyses of $\mathrm{CO}_{2}$ concentration. A standard curve was preliminarily prepared by injecting the same volume of $\mathrm{CO}_{2}$ gas $(1$ or $2 \mathrm{ml})$ in various known concentrations $(Y)$, which gave a linear response curve to the spike heights $(Y=11.08 X+20.15$, $r=0.99, p<0.001$ ).

\section{Carbon and nitrogen contents in soil}

After cultivation of the fields, soil samples from each field were collected at five flux-measurement points from seven depths, 2.5, 10, 20, 30, 40,50 and $60 \mathrm{~cm}$. Samples of dried soil $\left(105^{\circ} \mathrm{C}\right)$ were ground to determine the carbon and nitrogen contents. Each dried sample was sieved through a $0.2-\mathrm{mm}$ mesh sieve, care being taken to sieve the entire sample. This portion of the sample was analysed for total carbon and nitrogen using an automatic carbon and nitrogen analyser (C-N Corder MT-600, Yanako, Kyoto, Japan)

\section{Results}

Figure 2 shows the vertical distribution of the carbon and nitrogen contents in three soil types. The soil carbon and nitrogen contents were constant to a depth of $20 \mathrm{~cm}$, but below that decreased with depth in each soil. The contents differed, however, between the soil types. The values of carbon to $20-\mathrm{cm}$ depth were approximately $20 \%$ for peat, $1.7 \%$ for sand and $3.5 \%$ for clay soil, and those of nitrogen were approximately $1.3 \%$ for peat, $0.13 \%$ for sand and $0.25 \%$ for clay soil. Storage of carbon within the upper 60 -cm layers of soil amounted to $54.4 \mathrm{kgC} \mathrm{m}^{-2}$ in the peat, $16.9 \mathrm{kgC} \mathrm{m}^{-2}$ in the clay and $8.4 \mathrm{kgC}^{-2}$ $\mathrm{m}^{-2}$ in the sandy soil. 


\section{AGRICULTURAL AND FOOD SCIENCE IN FINLAND}

Koizumi, H. et al. Carbon dioxide evolution from agricultural ecosystems

Table 2. Temperature $\left({ }^{\circ} \mathrm{C}\right)$ of air, snow and soil on the measurement days in three soil types.

\begin{tabular}{lcccccccc}
\hline & \multicolumn{2}{c}{ Peat } & & \multicolumn{2}{c}{ Sand } & & \multicolumn{2}{c}{ Clay } \\
\cline { 2 - 3 } \cline { 8 - 9 } \cline { 8 - 9 } & March & July & & March & July & & March & July \\
\hline Air $(+50 \mathrm{~cm})$ & -1.0 & +17.5 & & +1.8 & +18.7 & & +1.8 & +16.6 \\
Snow $(-10 \mathrm{~cm})$ & -1.4 & - & & -0.3 & - & & +0.0 & - \\
Soil $(0 \mathrm{~cm})$ & -0.5 & +20.1 & & +0.0 & +20.3 & & +0.2 & +18.4 \\
Soil $(-2 \mathrm{~cm})$ & +0.2 & +19.0 & & +0.6 & +18.9 & & +0.5 & +17.5 \\
\hline
\end{tabular}

The average snow depth on the measurement days was approximately $20 \mathrm{~cm}$ for the peat, $15 \mathrm{~cm}$ for the sand, and $25 \mathrm{~cm}$ for the clay soil. Table 2 shows the temperatures of air, snow and soil on the measurement days in each soil type. The air temperatures in winter were between -1 and $+2^{\circ} \mathrm{C}$ in the three soil types, and those in the summer between 17 and $19^{\circ} \mathrm{C}$. The summer air temperatures were slightly higher than the average maximum air temperature of the warmest month (July, $\left.15.8^{\circ} \mathrm{C}\right)$ as is normal for these soil types. The winter soil temperatures at $2-\mathrm{cm}$ depth were between 0 and $1{ }^{\circ} \mathrm{C}$ in each soil type, and the summer soil temperatures between 18 and $19^{\circ} \mathrm{C}$. The snow temperatures below $10-\mathrm{cm}$ depth were almost $0^{\circ} \mathrm{C}$ in all soil type fields (Table 2).

Concentrations of $\mathrm{CO}_{2}$ in the snowpack (average of five measurement points) increased with snow depth and its gradients differed from one soil to another (Fig. 3). The concentration decreased linearly between the snow surface and $15-\mathrm{cm}$ or $20-\mathrm{cm}$ depth. The gradient was smallest in the sand soil, but largest in the peat soil; it was intermediate in the clay soil.

The winter fluxes of $\mathrm{CO}_{2}$ from the snowpack (average of five measurement points) differed depending on the soil types, ranging from 18 to $27 \mathrm{mg} \mathrm{CO}_{2} \mathrm{~m}^{-2} \mathrm{~h}^{-1}$ for the $\mathrm{CC}$ method and from 10 to $27 \mathrm{mg} \mathrm{CO}_{2} \mathrm{~m}^{-2} \mathrm{~h}^{-1}$ for the DM method (Table 3 ). Both methods showed a similar differential pattern between soil types. The snow-covered fields in the peat and sand soils produced the largest and smallest amounts of $\mathrm{CO}_{2}$, respectively. The clay soil had intermediate winter fluxes. The variance in the winter fluxes within the same soil types was relatively larger in the DM than in the CC method (Table 3). The results obtained with the $\mathrm{CC}$ method indicated that the average summer $\mathrm{CO}_{2}$ evolution was 14 24 times higher than the winter evolution.

\section{Discussion}

Carbon dioxide in soils derives primarily from root respiration and microbial oxidation of organic matter (Witkamp and Frank 1969, Wildung et al. 1975, Kowalenko et al. 1978, Heinemeyer et al. 1989, Koizumi et al. 1993, Nakadai et al. 1996). Therefore, low temperatures during the snow-covered period retard $\mathrm{CO}_{2}$ production in soils. Based on some empirical or theoretical studies (Steudler et al. 1989, Bouwman 1990), most $\mathrm{CO}_{2}$ budgets have been calculated by assuming that $\mathrm{CO}_{2}$ exchange stops when the soil is covered with snow or soil temperatures drop to around $0^{\circ} \mathrm{C}$. The present study, however, suggests that the assumption for the winter $\mathrm{CO}_{2}$ budget is incorrect. In sub-alpine and cool-temperate regions, soils at 5- to $10-$ or $20-\mathrm{cm}$ depth, or the active layer of soil respiration (Crill 1991), never freeze during the winter because of the thermal insulation effect of the snow cover (Sommerfeld et al. 1993). This allows soil microorganisms to produce enough $\mathrm{CO}_{2}$ to form gradients within the snowpack (Fig. 3). It is suggested that each soil type serves as a source of $\mathrm{CO}_{2}$ in winter.

Table 3 also indicates that the $\mathrm{CO}_{2}$ evolution rates in winter were higher in the peat than in 


\section{AGRICULTURAL AND FOOD SCIENCE IN FINLAND}

Vol. 5 (1996): 421-430.
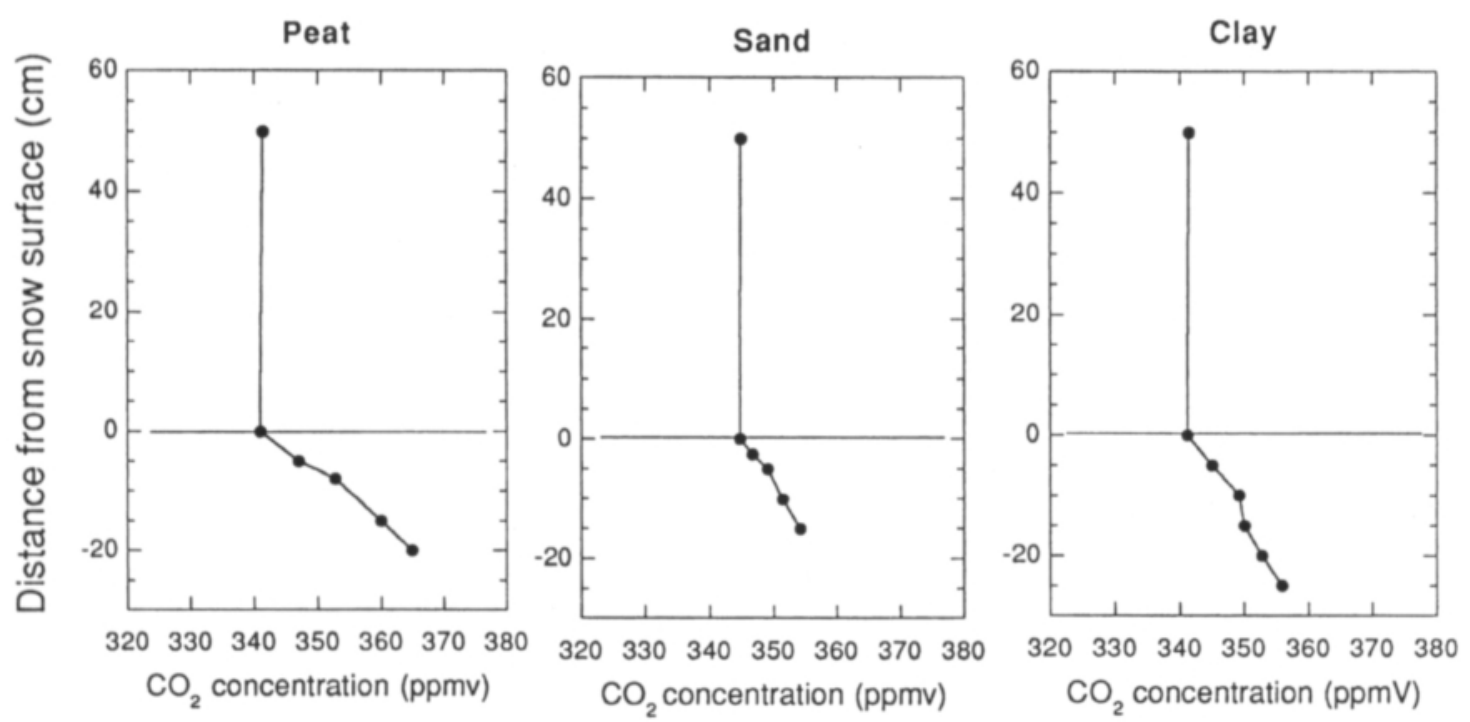

Fig. 3. Profiles of $\mathrm{CO}_{2}$ concentration in air and snowpack in peat, sand and clay soil. Results are averages of five measurement points. Horizontal solid lines refer to snow surface.

the sand or clay soil fields. The $\mathrm{CO}_{2}$ evolution rates in the peat soil were about twice as high as those in the sand soil. These results suggest that the higher availability of organic matter in the peat soil results in higher rates of $\mathrm{CO}_{2}$ production in that soil (cf. Fig. 2).

Using the DM method it was estimated that the snow-covered fields in southern Finland can evolve $10 \sim 27 \mathrm{mg}$ of $\mathrm{CO}_{2}$ per $\mathrm{m}^{2}$ per hour on some winter days (Table 3 ). The winter fluxes show somewhat lower values than those calculated by Sommerfeld et al. (1993) from the $\mathrm{CO}_{2}$ profiles in the snowpacks of sub-alpine meadow, southeastern Wyoming. Nakane (1978) estimated $\mathrm{CO}_{2}$ evolution rates from Japanese cooltemperate beech/fir forest soils beneath the snowpack to be between 50 and $70 \mathrm{mg}$ per $\mathrm{m}^{2}$ per hour. Mariko et al. (1994) also demonstrated that the $\mathrm{CO}_{2}$ evolution rates from snow-covered soils in four Japanese cool-temperate deciduous broadleaved and evergreen needle forests ranged from 20 to $75 \mathrm{mg}$ per $\mathrm{m}^{2}$ per hour. Here, direct measurement with the CC method also demonstrated remarkable fluxes of 18 27 $\mathrm{mg}$ per $\mathrm{m}^{2}$ per hour (Table 3 ), indicating the validity of the results obtained with indirect measurements or estimation. Thus the winter fluxes represent an important part of the annual

Table 3. Average and standard deviation of $\mathrm{CO}_{2}$ evolution rate $\left(\mathrm{mgCO}_{2} \mathrm{~m}^{-2} \mathrm{~h}^{-1}\right)$ from snow surface (winter) and soil surface (summer) in three soil types. The flux was measured directly using the closed chamber method (CC method) and calculated using Fick's law from $\mathrm{CO}_{2}$ profiles over a 0-20 cm layer within the snowpack (DM method).

\begin{tabular}{llll}
\hline & Peat & Sand & Clay \\
\hline Winter & & & \\
CE* (CC method) & $27.4 \pm 16.9$ & $18.3 \pm 10.7$ & $21.0 \pm 13.2$ \\
& $(4.2 \%)$ & $(7.2 \%)$ & $(4.6 \%)$ \\
CE* (DM method) & $26.8 \pm 21.5$ & $10.0 \pm 6.7$ & $16.1 \pm 11.3$ \\
& $(4.0 \%)$ & $(3.9 \%)$ & $(3.6 \%)$
\end{tabular}

Summer

CE* (CC method) $\quad 645.9 \pm 145.7 \quad 253.9 \pm 84.8 \quad 452.2 \pm 29.2$

*: $\mathrm{CE}$ refers to $\mathrm{CO}_{2}$ evolution rate.

Numerals in parentheses indicate the percentage of $\mathrm{CE}$ in summer.

Average $\mathrm{CO}_{2}$ flux was calculated from five measurment points. 


\section{AGRICULTURAL AND FOOD SCIENCE IN FINLAND}

\section{Koizumi, H. et al. Carbon dioxide evolution from agricultural ecosystems}

$\mathrm{CO}_{2}$ budget in snowy regions (Coyne and Kelley 1974, Nakane 1978, Mariko et al. 1994).

Still, it has not been established whether $\mathrm{CO}_{2}$ evolution through the snow surface changes during the winter period. Sommerfeld et al. (1993) stated that, as soil microorganisms remain active without change during the winter because there is no fluctuation in soil temperature (Solomon and Cerling 1987), the results obtained during limited study periods are representative of the entire winter. The actual winter fluxes, however, seem to change seasonally depending on snowfall. This is suggested by the findings of the previous study (Mariko et al. 1994) showing that the $\mathrm{CO}_{2}$ gradient within a thick snowpack is small compared with that within a thin snowpack, even in areas with almost the same vegetation (Kelley et al. 1968, Solomon and Cerling 1987). To understand the contribution of winter to the annual carbon budget, the flux must be determined throughout an entire winter period.

Seasonal comparison of $\mathrm{CO}_{2}$ evolution from each soil type can be made using data obtained with the $\mathrm{CC}$ method in the subarctic climate range. On the basis of these data, winter $\mathrm{CO}_{2}$ evolution in subarctic climate ranges is estimated to be between $4.2 \%$ and $7.2 \%$ of evolution in summer, when it is almost totally due to soil respiration. These percentages represent the extreme minimum fluxes on winter days in relation to the maximum fluxes on summer days with the highest annual temperature. Therefore, the winter/summer ratio of the $\mathrm{CO}_{2}$ evolution rate calculated from seasonally-integrated fluxes is estimated to exceed $4 \%$.

The snowpack influences winter $\mathrm{CO}_{2}$ evolution in both positive and negative ways. First, the snow insulates the soil thermally, allowing $\mathrm{CO}_{2}$ production to continue throughout the winter at temperatures above freezing. Second, the snow supplies water that participates in weath- ering reactions in the soil, allowing $\mathrm{CO}_{2}$ production to increase (Solomon and Cerling 1987). Third, the snow causes the $\mathrm{CO}_{2}$ concentration in snow and soil to rise by partially capping the snow-soil column and by lowering the soil diffusion coefficient as the soil pores are filled with water from the melting snowpack. Moreover, there is the interesting suggestion of Sommerfeld et al. (1993), who pointed out that the snow feeds fungi and bacteria, making them able to respire there.

Direct measurement (CC method) showed the same trend in the difference in winter fluxes between sites as the indirect measurement (DM method). The CC method tended to show larger absolute average fluxes than the DM method even when the measurements were made at the same points and on the same day. The variance in the fluxes within each soil type tended to be slightly larger with the DM than with the CC method. These differences may be due to the qualitative difference in their measurement principles, which result in different kinds of measurement errors (Rolston 1986). Of great practical interest is to know which of the methods is more reliable in situ. This will be determined in a further study to be conducted by the authors. The present study does at least suggest, however, that the CC method is acceptable for the practical measurement of $\mathrm{CO}_{2}$ flux through the snow surface.

Acknowledgements. The authors thank Matti Matilainen and Arto Timonen, Agricultural Research Centre of Finland, and Harri Jalli, Helsinki University, for their kind assistance during the field work in Jokioinen, and Dr Masayuki Yokosawa, National Institute of Agro-Environmental Sciences, for his technical advice on the calculation of gas flux. The authors also thank Hiroko Nemoto for her help in this study. This research was partially supported by a grant from the Science and Technology Agency of Japan. 
Vol. 5 (1996): 421-430.

\section{References}

Barry, R.G. 1992. Climate-ice interactions. In: Encyclopedia of Earth System Science Vol. 1. Academic Press, Sandiego. p. 517-524.

Bekku, Y., Koizumi, H., Nakadai, T. \& Iwaki, H. 1995. Measurement of soil respiration using closed chamber method: An IRGA technique. Ecological Research 10: 369-373.

- , Koizumi, H., Oikawa, T. \& Iwaki, H. 1996. Examination of four methods for measuring soil respiration. Applied Soil Ecology (in press).

Bouwman, A.F. 1990. Exchange of greenhouse gases between terrestrial ecosystems and the atmosphere. In: Bouwman, A. F. (ed.) Soils and the Greenhouse Effect. Wiley \& Sons, Chichester. p. 61-127.

Coyne, R.I. \& Kelley, J.J. 1974. Variations in carbon dioxide across an arctic snowpack during spring. Journal of Geophysical Research 79: 799-802.

Crill, P.M. 1991. Seasonal patterns of methane uptake and carbon dioxide release by a temperate woodland soil. Global Biogeochemical Cycles 5: 319-334.

Heinemeyer, O., Insam, H., Kaiser, E.A. \& Walenzik, G. 1989. Soil microbial biomass and respiration measurements: An automated technique based on infra-red gas analysis. Plant and Soil 116: 191-195.

Kelley, Jr. J. J., Weaver, D.F. \& Smith, B.P. 1968. The variation of carbon dioxide under the snow in the Arctic. Ecology 49: 358-361.

Koizumi, H., Usami, Y. \& Satoh, M. 1993. Carbon dynamics and budgets in three upland double-cropping agro-ecosystems in Japan. Agriculture, Ecosystems and Environment 43: 235-244.

Kowalenko, C.G., Ivarson, K.C. \& Cameron, D.R. 1978. Effect of moisture content, temperature and nitrogen fertilization on carbon dioxide evolution from field soils. Soil Biology \& Biochemistry 10: 417-423.

Mariko, S., Bekku, Y. \& Koizumi, H. 1994. Efflux of carbon dioxide from snow-covered forest floors. Ecological Research 9: 343-350.

Nakadai, T., Koizumi, H., Bekku, Y. \& Totsuka T. 1996. Carbon dioxide evolution from upland rice-barley dou- ble-cropping field in central Japan. Ecological Research 11: 217-227.

Nakane, K. 1978. Dynamics of soil organic carbon and its seasonal variation in a cool-temperate beech/fir forest on Mt. Odaigahara. Japanese Journal of Ecology 28: 335-346 (in Japanese with English summary).

Osozawa, S. 1987. Measurement of soil-gas diffusion coefficient for soil diagnosis. Soil Physical Conditions and Plant Growth, Japan 55: 53-60 (in Japanese with English summary).

Rolston, D.E. 1986. Gas flux. In: Klute, A. (ed.) Methods of Soil Analysis, Part 1. Physical and Mineralogical Methods. p. 1103-1119.

Solomon, D.K. \& Cerling, T.E. 1987. The annual carbon dioxide cycle in a montane soil: Observations, modeling, and Implications for weathering. Water Resources Research 23: 2257-2265.

Sommerfeld, R.A., Mosier, A.R. \& Musselman, R.C. 1993. $\mathrm{CO}_{2}, \mathrm{CH}_{4}$ and $\mathrm{N}_{2} \mathrm{O}$ flux through a Wyoming snowpack and implication for global budgets. Nature 361 : 140-142.

-, Musselman, R.C. \& Reuss, J.O. 1991. Preliminary measurements of $\mathrm{CO}_{2}$ in melting snow. Geophysical Research, Letters 18: 1225-1228.

Steudler, P.A., Bowden, R.D., Melillo, J.M. \& Aber, J.D. 1989. Influence of nitrogen fertilization on methane uptake in temperate forest soils. Nature 341: 314-316.

Taylor, B.R. \& Parkinson, D. 1988. Does repeated freezing and thawing accelerate decay of leaf litter. Soil Biology \& Biochemistry 20: 657-665.

van Bavel, C.H.M. 1951. A soil aeration theory based on diffusion. Soil Science 72: 33-46.

Wildung, R.E., Garland, T.R. \& Buschbom, R.L. 1975. The interdependent effects of soil temperature and water content on soil respiration rate and plant root decomposition in arid grassland soils. Soil Biology \& Biochemistry 7: 373-378.

Witkamp, M. \& Frank, M.L. 1969. Evolution of $\mathrm{CO}_{2}$ from litter, humus and subsoil of a pine stand. Pedobiologia 9: 358-365. 
Koizumi, H. et al. Carbon dioxide evolution from agricultural ecosystems

\title{
SELOSTUS
}

\section{Hiilidioksidin kulku lumipeitteisessä ja paljaassa maassa}

\author{
Hiroshi Koizumi, Markku Kontturi, Shigeru Mariko ja Timo Mela \\ National Institute of Agro-Environmental Sciences, Japani, Maatalouden tutkimuskeskus \\ ja Sugadaira Montane Research Center, Japani
}

Hiilidioksidin vapautumista lumipeitteisestä ja paljaasta maasta mitattiin suorasti ja epäsuorasti Suomen maaperästä. Mittaukset tehtiin turve-, hiekka- ja savimaasta. Suorissa mittauksissa käytettiin suljetun kammion menetelmää ja epäsuorissa Fickin diffuusiomallia.

Kaikkien em. maalajien talvilämpötila vaihteli $2 \mathrm{~cm}: \mathrm{n}$ syvyydessä $0 \mathrm{ja}+1^{\circ} \mathrm{C}$ välillä. Hiilidioksidipitoisuus lumikerroksen sisällä oli sitä korkeampi mitä paksumpi lumikerros oli. Lumen hiilidioksidipitoisuudesta mitattu keskimääräinen hiilidioksidivir- taus vaihteli $10-27 \mathrm{mg} \mathrm{CO}_{2} \mathrm{~m}^{-2} \mathrm{~h}^{-1}$ diffuusiomallilla ja $18-27 \mathrm{mg} \mathrm{CO}_{2} \mathrm{~m}^{-2} \mathrm{~h}^{-1}$ suljetun kammion menetelmällä mitattuna.

Tämän tutkimuksen mukaan lumi on hyvä maan lämpöeriste, ja $\mathrm{CO}_{2}$ :n tuotanto jatkuu maassa lämpötilojen pysyessä lumipeitteen alla jäätymispisteen yläpuolella. Maaperästä vapautuu ilmakehään hiilidioksidia lumipeitteen läpi. Hiilidioksidin muodostumista talvella ja kesällä kuvaavan suhdeluvun arvioitiin olevan noin $4 \%$. Täten merkittävä osa vuotuisista hiilidioksidipäästöistä syntyy talvella. 